\title{
Multidimensional Assessment of Variation of Physio-Chemical Parameters of the Liwiec River Basin Waters
}

\author{
Katarzyna Rymuza \\ 1 Faculty of Natural Sciences, Siedlce University of Natural Sciences and Humanities, ul. Prusa 14, \\ 08-110 Siedlce, Poland \\ e-mail: katarzyna.rymuza@uph.edu.pl
}

\begin{abstract}
The objective of the work was to utilise multidimensional statistical methods to assess the physio-chemical status of waters of the River Liwiec catchment. The water quality assessment and comparison in terms of fifteen parameters were based on the monitoring data collected at eight measurement points in 2017. The principal component analysis demonstrated that the water quality in the River Liwiec catchment was principally conditioned by water temperature, $\mathrm{pH}$, soluble oxygen content, nitrite nitrogen content and organic carbon content. The cluster analysis conducted based on principal components yielded three clusters of measurement points. The first cluster included the following measurement points: Liwiec-Kamieńczyk, Liwiec Wólka Proszewska, Liwiec Borzychy and Liwiec Krześlin. The waters at these points contained the least organic carbon and ammonium nitrogen. The second cluster consisted of the Muchawka Żytnia and Muchawka Rakowiec tributaries characterised by the highest amount of phosphorus, Kiejdhal nitrogen, ammonium nitrogen, nitrite nitrogen and organic carbon. The third cluster was made up of the Kostrzyń Proszew and Kostrzyń Łączka tributaries, both having the lowest values of nearly all the examined parameters.
\end{abstract}

Keywords: pollution of surface waters, cluster analysis, quality ranking, the River Liwiec

\section{INTRODUCTION AND WORK OBJECTIVE}

The River Liwiec is a left-bank tributary of the River Bug. With a length of about $126 \mathrm{~km}$, its source is found in the vicinity of Sobicze, Zbuczyn Commune (Gmina), Siedlce County (Powiat). The river runs through the Siedlecka Upland, Węgrów Basin and Wołomińska Lowland and terminates in the vicinity of Kamieńczyk, the Lower Bug Valley [Starczewski et al. 2014]. There are no embankments along the river channel and the Liwiec is barely regulated, apart from the upper reach and several parts of the lower reach [Kot 1995]. As the river runs close to a large urban agglomeration, it has become a very attractive place of weekend recreation. Thus, the quality of its water has become of particular importance, because it conditions the river's social, economic and recreational use.

The quality of surface waters is modified by natural and anthropogenic factors [Bogdał and
Ostrowskia 2007, Grabińska 2011, Kanownik et al. 2013]. The natural factors include geological makeup, soil type, climatic and hydrological conditions as well as the processes occurring in the soil environment. In turn, the Anthropogenic factors encompass the type of terrain use and management [Bogdał et al. 2012, Kowalik et al. 2014, 2015]. In the basins, the total area of which includes a marked share of ploughed land, the quality of surface waters is predominantly affected by crop- and fertiliser-related pollutants [Kiryluk and Rauba 2009, Kornaś and Grześkowiak 2011, Szymczyk and Rafałowska 2011]. The waters leaving the basins located in agricultural areas tend to contain the highest concentration of nitrogen and phosphorus compounds [Ławniczak et al. 2008]. An accumulation of pollutants in the water environment may be also boosted by the wastewater from industrial facilities and urban agglomerations [Mosiej et al. 2007, LampartKałużniacka et al. 2012, Policht-Latawiec et al. 
2013, 2015]. The pollution poses a threat to the proper functioning of water ecosystems [Jaskuła et al. 2015, Pytka et al. 2013].

The water quality assessment is performed by Voivodeship Inspectorates for Environmental Protection (WIOŚ). The monitoring results consist of a large amount of data which is difficult to analyse and interpret unequivocally. As a result, such analyses employ multidimensional statistical methods such as principal component analysis, cluster analysis, factorial analysis or multidimensional comparative analysis [Akin et al. 2011, Boyacioglu et al. 2010, Brahman et al. 2013].

The objective of the work was to (i) use multidimensional statistical methods for assessing the physio-chemical condition of waters of individual stretches of the River Liwiec and its tributaries, and (ii) rank the quality of these waters based on the following multidimensional statistical methods of data analysis: principal component, cluster analysis and multidimensional comparative analysis using the zero unitarisation method.

\section{MATERIALS AND METHODS}

The analysis of monitoring data collected in the year 2017 was performed, including the following eight measurement points: LiwiecKamieńczyk, Liwiec-Krześlin, Liwiec-Wólka Proszewska, Liwiec Borzychy, Muchawka-Rakowiec, Muchawka-Żytnia, Kostrzyń-Łączka and Kostrzyń- Proszew.

The following chemical parameters were analysed: $\mathrm{X}_{1}$ - water temperature $\left({ }^{\circ} \mathrm{C}\right), \mathrm{X}_{2}-$ dissolved oxygen $\left(\mathrm{mg} \mathrm{O}_{2} / 1\right), \mathrm{X}_{3}-\mathrm{BOD} 5\left(\mathrm{mg} \mathrm{O}_{2} / \mathrm{l}\right)$, $\mathrm{X}_{4}$ - total organic carbon content $(\mathrm{mg} \mathrm{C} / \mathrm{l}), \mathrm{X}_{5}$
- conductivity at $20^{\circ} \mathrm{C}(\mathrm{uS} / \mathrm{cm}), \mathrm{X}_{6}$ - dissolved substances $(\mathrm{mg} / \mathrm{l}), \mathrm{X}_{7}-$ overall hardness $(\mathrm{mg}$ $\left.\mathrm{CaCO}_{3} / 1\right), \mathrm{X}_{8}$ - water $\mathrm{pH}, \mathrm{X}_{9}$ - ammonium nitrogen (mg N-NH$/ 1), X_{10}-$ Kjeldahl nitrogen (mg $\mathrm{N} / \mathrm{l}), \mathrm{X}_{11}$ - nitrate nitrogen $\left(\mathrm{mg} \mathrm{N}-\mathrm{NO}_{3} / \mathrm{l}\right), \mathrm{X}_{12}-$ nitrite nitrogen $\left(\mathrm{mg} \mathrm{N} \mathrm{NO}_{2} / \mathrm{l}\right), \mathrm{X}_{13}$ - total nitrogen (mg N/l), $\mathrm{X}_{14}$ - phosphate phosphorus content (mg $\left.\mathrm{PO}_{4} / 1\right), \mathrm{X}_{15}$ - total phosphorus content (mg P/l).

The initial data analysis consisted in calculating the basic statistical measures: mean, variation coefficient, and maximum and minimum values.

The principal component analysis was used in order to analyse the multidimensional variation of physio-chemical parameters at measurement points. As the examined indicators had different units, the variables were standardised. Selection of the number of components included in further analysis was based on the Kaisler criterion according to which analysis of the components with eigenvalue greater than 1 is performed. Next, the cluster analysis was applied to group the measurement points located in the River Liwiec basin according to water quality. The grouping was based on the Ward's method, and employed the Euclidean distance. The Mojena rule was used to determine the dendrogram cut-off point [Mojena 1977].

The measurement points were ranked according to the physio-chemical quality of waters taking into account all the parameters and based on multidimensional comparative analysis which relies on obtaining, through normalisation, unitless values of characteristics. As a result, a single (instead of many) synthetic variable is formed, which represents a complex phenomenon.

Normalisation of variables was based on the method of zero unitarisation. The character of the

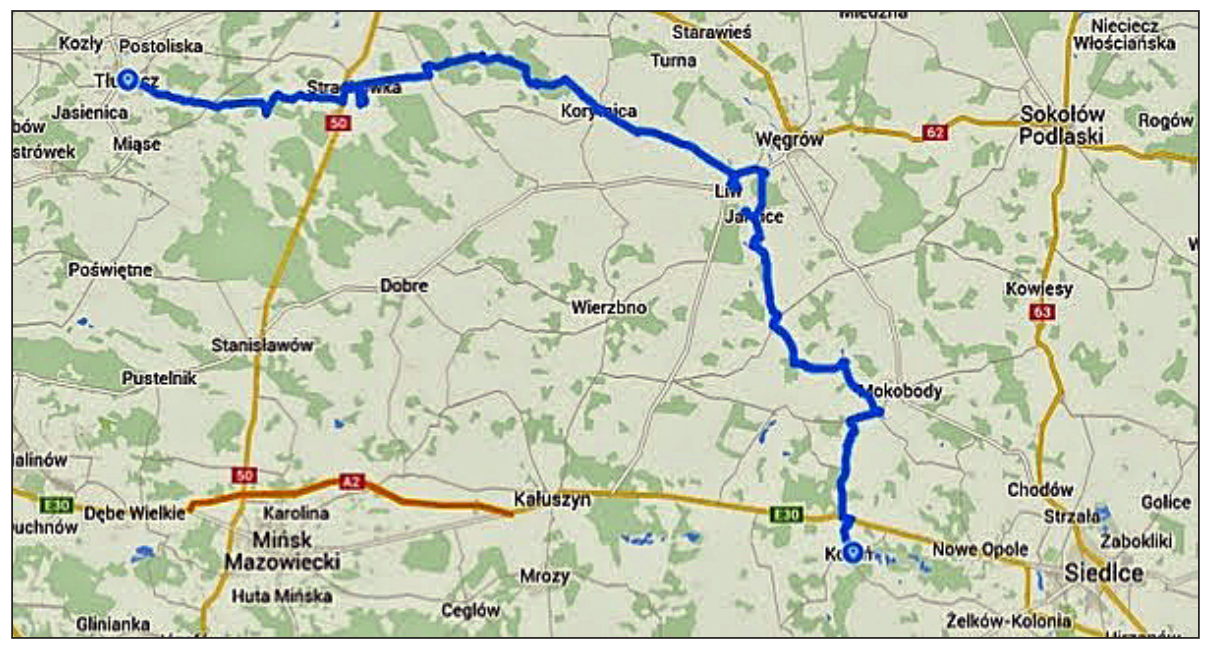

Fig. 1 The River Liwiec basin 
variables was determined prior to normalisation. The following stimulants were assumed: water temperature, water $\mathrm{pH}$ and dissolved oxygen content. The remaining variables were classified as destimulants. The normalisation of stimulants was preformed according to the following formula [Kukuła 2000]:

$$
z_{i j}=\frac{1}{b_{i}-a_{i}}\left(x_{i j}-a_{i}\right)
$$

In turn, normalisation of destimulants was carried out using the following formula:

$$
z_{i j}=\frac{1}{b_{i}-a_{i}}\left(b_{i}-x_{i j}\right)
$$

where: $z_{i j}$ - normalised value of the $\mathrm{i}$-th characteristic and $\mathrm{j}$-th river section, $\mathrm{i}=1, \ldots, 19$, $\mathrm{j}=1, \ldots, 12$,

$X_{i j}$ - value of the $\mathrm{i}$-th characteristic and $\mathrm{j}$-th river section, $\mathrm{i}=1, \ldots, 19, \mathrm{j}=1, \ldots, 12$, $a_{i}-$ minimum value of the $i$-th characteristic,

$b_{i}-$ maximum value of the $\mathrm{j}$-th characteristic.

The obtained values of normalised variables were used to calculate, for each measurement point, the synthetic measure (aggregate evaluation) following the formula:

$$
\mathrm{q}_{\mathrm{i}}=\frac{1}{\mathrm{~s}} \sum_{\mathrm{i}=1}^{\mathrm{s}} \mathrm{z}_{\mathrm{ij}},
$$

where $s$ denotes the number of variables entering analysis.

The values of the synthetic measure $\mathrm{q}_{\mathrm{q}}$ were put in order to rank river stretches and its tributaries according to water quality.

All the calculations were performed in STATISTICA 12.0 and EXCEL.

\section{ANALYSIS OF RESULTS}

Means, minimum and maximum values of water quality parameters for the River Liwiec Basin are shown in Table 1. The lowest variation was found for $\mathrm{pH}(3.792 \%)$ and water temperature $(\mathrm{V}=7.85 \%)$, it being the highest for ammonium nitrogen (90.25\%) and nitrate nitrogen (36.36\%).

Principal component analysis demonstrated that the water quality in the River Liwiec basin was affected by the characteristic associated with the first three principal components: PC1, PC2 and PC3 (as indicated by their eigenvalues which exceed 1). The components accounted for

\begin{tabular}{|c|c|c|c|c|c|c|}
\hline \multirow{2}{*}{ Parameter } & \multirow{2}{*}{ mean } & \multirow{2}{*}{ V } & \multicolumn{2}{|r|}{$\min$} & \multicolumn{2}{|r|}{$\max$} \\
\hline & & & value & River & value & River \\
\hline Water temperature & 16.744 & 7.853 & 14.950 & $\begin{array}{c}\text { Muchawka } \\
\text { Rakowiec }\end{array}$ & 19.233 & Liwiec Kamieńczyk \\
\hline Dissolved oxygen & 7.848 & 14.709 & 6.583 & Muchawka Żytnia & 9.833 & Liwiec Kamieńczyk \\
\hline BOD5 & 3.123 & 10.824 & 2.683 & Muchawka Żytnia & 3.767 & Liwiec Kamieńczyk \\
\hline Total organic carbon & 13.159 & 10.317 & 10.958 & Liwiec Kamieńczyk & 15.700 & $\begin{array}{c}\text { Muchawka } \\
\text { Rakowiec }\end{array}$ \\
\hline Conductivity at $20^{\circ} \mathrm{C}$ & 461.563 & 12.459 & 360.333 & Kostrzyń Łączka & 566.500 & Liwiec Wólka \\
\hline Dissolved substances & 306.458 & 12.602 & 234.333 & Kostrzyń Łączka & 376.333 & $\begin{array}{l}\text { Liwiec Wólka } \\
\text { Proszewska }\end{array}$ \\
\hline Overall hardness & 239.958 & 12.463 & 190.333 & Kostrzyń Łączka & 291.333 & Liwiec Krześlin \\
\hline $\mathrm{pH}$ & 7.440 & 3.792 & 6.983 & Kostrzyń-Łączka & 7.967 & Liwiec Kamieńczyk \\
\hline Ammonium nitrogen & 0.137 & 90.250 & 0.029 & Liwiec Kamieńczyk & 0.443 & $\begin{array}{c}\text { Muchawka } \\
\text { Rakowiec }\end{array}$ \\
\hline Kjeldahl nitrogen & 1.969 & 15.181 & 1.610 & Kostrzyń Proszew & 2.582 & $\begin{array}{c}\text { Muchawka } \\
\text { Rakowiec }\end{array}$ \\
\hline Nitrate nitrogen & 1.636 & 41.258 & 0.620 & Kostrzyń-Łączka & 2.603 & $\begin{array}{l}\text { Liwiec Wólka } \\
\text { Proszewska }\end{array}$ \\
\hline Nitrite nitrogen & 0.026 & 36.360 & 0.013 & Liwiec Kamieńczyk & 0.041 & $\begin{array}{c}\text { Muchawka } \\
\text { Rakowiec }\end{array}$ \\
\hline Total nitrogen & 3.645 & 21.122 & 2.427 & Kostrzyń Łączka & 4.454 & Liwiec Kamieńczyk \\
\hline Phosphate phosphorus (V) & 0.069 & 16.990 & 0.052 & Liwiec Krześlin & 0.086 & Muchawka Żytnia \\
\hline Total phosphorus & 0.164 & 17.012 & 0.129 & Kostrzyń Proszew & 0.226 & $\begin{array}{c}\text { Muchawka } \\
\text { Rakowiec }\end{array}$ \\
\hline
\end{tabular}
about $90 \%$ of the total (combined) variance of the

Table1. Basic statistics of physio-chemical parameters of the River Liwiec Basin 
multidimensional variation in the water quality parameters (Table 2).

The first principal component was strongly positively associated with the water temperature (0.961), water $\mathrm{pH}(0.954)$, dissolved oxygen content (0.899) and nitrite nitrogen content (0.807), and negatively correlated with organic carbon content $(-0.835)$. The parameters had the greatest share in the multivariate variation in water quality. The values of correlation coefficients indicate that the in river stretches where water contained relatively high amounts of organic carbon, lesser dissolved oxygen, lower temperature and lower $\mathrm{pH}$ values were observed. The total and phosphate phosphorus contents, nitrite and Kjeldahl nitrogen contents as well as dissolved substances were the most strongly associated with the second principal component, which accounted for about $33 \%$ variation. An increase in the amount of both forms of phosphorus was followed by a rise in the nitrite and Kjeldahl nitrogen content and dissolved substances. The third component, predominantly associated with BOD5 (0.910), accounted for over $12 \%$ of multivariate water quality in the Liwiec River basin (Table 1). Nachlik [2004] claims that depending on their concentration, the nitrogen compounds in surface waters may stimulate the development of algae and reduce the dissolved oxygen levels. The concentration of the nitrogen and phosphorus compounds in river water is low in the basins with predominantly sandy soils, and a rich forest cover as well as high in the basins where soils are predominantly compacted and used for intensive agricultural production purposes [Melcer and Olejnik 2006]. Some authors stress the fact that a rich forest cover contributes to the reduced infiltration of pollutants from surface sources to the water. In such basins, a decline in the concentration of these compounds in the river waters along the river course is observed because of the process called self-purification of waters [Górecki and Olejnik 2005].

The location of characteristics in the system of the first two principal components indicates that there was a strong positive association of the organic carbon content with the ammonium nitrogen content, as well as the total nitrogen content and dissolved substances with conductivity. Moreover, at the measurement points where the organic nitrogen content was higher, a lower dissolved oxygen content was found (Fig. 1).

The cluster analysis yielded three clusters of measurement points in the River Liwiec basin which had different physio-chemical

Table 2. Eigenvalues and correlation coefficients between water quality parameters and three principal components

\begin{tabular}{|l|c|c|c|}
\hline \multicolumn{1}{|c|}{ Parameter } & PC1 & PC2 & PC3 \\
\hline Water temperature & 0.961 & 0.096 & 0.089 \\
\hline Dissolved oxygen & 0.899 & 0.170 & 0.351 \\
\hline BOD5 & 0.337 & -0.147 & -0.910 \\
\hline Total organic carbon & -0.835 & -0.447 & -0.391 \\
\hline Conductivity at 20 ${ }^{\circ} \mathrm{C}$ & 0.648 & -0.652 & -0.271 \\
\hline Dissolved substances & 0.603 & -0.722 & -0.386 \\
\hline Overall hardness & 0.663 & -0.640 & 0.152 \\
\hline pH & 0.954 & -0.007 & 0.360 \\
\hline Ammonium nitrogen & -0.683 & -0.576 & 0.485 \\
\hline Kjeldahl nitrogen & -0.266 & -0.711 & -0.003 \\
\hline Nitrate nitrogen & 0.807 & -0.519 & -0.209 \\
\hline Nitrite nitrogen & -0.442 & -0.788 & 0.167 \\
\hline Total nitrogen & 0.618 & -0.747 & -0.155 \\
\hline Phosphate phosphorus $(\mathrm{V})$ & -0.440 & -0.839 & 0.323 \\
\hline Total phosphorus & -0.353 & -0.850 & 1.97 \\
\hline Eigenvalue & 7.86 & 5.60 & 90.82 \\
\hline Cumulated variance & 46.26 & 79.25 & \\
\hline
\end{tabular}

1 - water temperature $\left({ }^{\circ} \mathrm{C}\right), 2$ - dissolved oxygen $\left(\mathrm{mg} \mathrm{O}_{2} / 1\right), 3-\mathrm{BOD} 5\left(\mathrm{mg} \mathrm{O}_{2} / 1\right), 4$ - total organic carbon $(\mathrm{mg} \mathrm{C} / 1)$, 5 - conductivity at $20^{\circ} \mathrm{C}(\mathrm{uS} / \mathrm{cm}), 6$ - dissolved substances $(\mathrm{mg} / \mathrm{l}), 7$ - overall hardness $\left(\mathrm{mg} \mathrm{CaCO}_{3} / 1\right), 8-$ water $\mathrm{pH}$, 9 - ammonium nitrogen $\left(\mathrm{mg} \mathrm{N}_{-} \mathrm{NH}_{4} / \mathrm{l}\right), 10$ - Kjeldahl nitrogen $(\mathrm{mg} \mathrm{N} / \mathrm{l}), 11$ - nitrate nitrogen $\left(\mathrm{mg} \mathrm{N}_{-} \mathrm{NO}_{3} / 1\right)$, 12 - nitrite nitrogen $\left(\mathrm{mg} \mathrm{N}-\mathrm{NO}_{2} / \mathrm{l}\right), 13$ - total nitrogen $(\mathrm{mg} \mathrm{N} / \mathrm{l}), 14$ - phosphate phosphorus $\left(\mathrm{mg} \mathrm{PO}_{4} / \mathrm{l}\right)$, 15 - total phosphorus (mg P/l). 
parameters of water (Fig. 3). The first cluster included four measurement points: LiwiecKamieńczyk, Liwiec Wólka Proszewska, Liwiec Borzychy and Liwiec Krześlin. The second cluster consisted of the Muchawka Żytnia and Muchawka Rakowiec tributaries, and the third one was made up of Kostrzyń Proszew and Kostrzyń Łączka (Fig. 2).

The waters of the measurement points forming group 1 had the highest mean values of most physio-chemical parameters, that is: water temperature, dissolved oxygen content, BOD5, conductivity, dissolved substances, overall hardness and nitrate nitrogen content. Group 1 had the lowest values of organic carbon content and ammonium nitrogen content. The waters in group 3 (tributary of the River Kostrzyń) had the lowest values of almost all the parameters excluding dissolved oxygen content, ammonium and nitrite nitrogen contents, and phosphate phosphorus content. The tributary of the River Liwiec - Muchawka - contained the highest amount of phosphorus, Kjeldahl nitrogen, ammonium and nitrite nitrogen, and organic carbon (Table 2).

Table 4 presents the measurement points ranked according to water quality. The values of the synthetic variable indicate that water at the Kostrzyń Proszew and Kostrzyń Łączka measurement points was of the best quality, as it had the lowest values of dissolved substances, overall hardness, most of the nitrogen forms and total phosphorus. The worst parameters were found for the waters of the MuchawkaŻytnia and Muchawka-Rakowiec rivers, as they had the highest amounts of e.g.: organic carbon, phosphorus and all the nitrogen forms. The research by Grabińska [2011] as well as Szymczyk and Rafałowska [2011] demonstrated that the main sources of surface water pollution with nitrogen and phosphorus compounds include the run-off of the pollutants from cultivated land and wastewater. High fertilisation levels may also contribute to the leaching and transfer of these compounds into surface waters [Kiryluk and Rauba 2011].

\section{CONCLUSIONS}

1. Principal component analysis demonstrated that the waters of the River Liwiec at the analysed points were the most affected by characteristics associated with the first principal component $\mathrm{PC} 1$ (water temperature, water $\mathrm{pH}$, dissolved oxygen content, nitrite nitrogen content and organic carbon content).

2. The values of correlation coefficients indicate that in the river stretches where water contained relatively high amounts of organic carbon, lesser dissolved oxygen, lower temperature and lower $\mathrm{pH}$ values were observed.

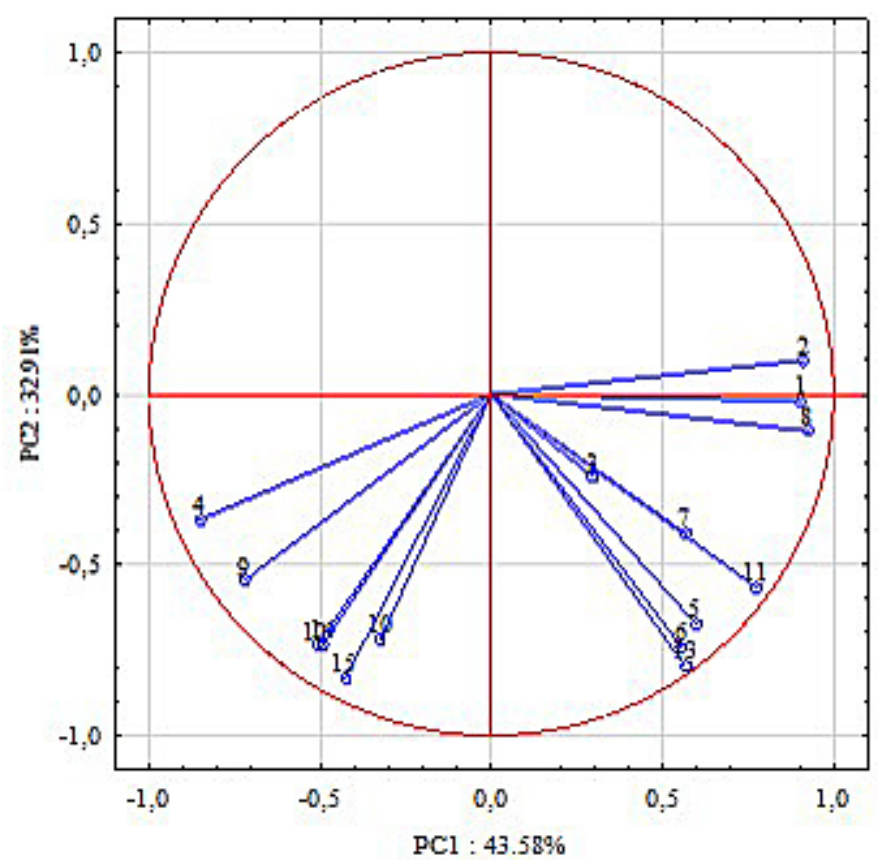

Fig. 2. Location of physio-chemical parameters of the River Liwiec waters in the space of the first and second principal component 
Table 3. Mean values of characteristics obtained by means of cluster analysis

\begin{tabular}{|l|c|c|c|}
\hline \multicolumn{1}{|c|}{ Parameter } & Group 1 & Group 2 & Group 3 \\
\hline Water temperature & 17.65 & 15.84 & 15.83 \\
\hline Dissolved oxygen & 8.83 & 6.67 & 7.06 \\
\hline BOD5 & 3.21 & 3.10 & 2.97 \\
\hline Total organic carbon & 12.19 & 14.76 & 38.50 \\
\hline Conductivity at 20 ${ }^{\circ} \mathrm{C}$ & 499.42 & 465.50 & 251.50 \\
\hline Dissolved substances & 330.46 & 313.42 & 200.50 \\
\hline Overall hardness & 262.21 & 234.92 & 7.21 \\
\hline pH & 7.65 & 7.25 & 0.13 \\
\hline Ammonium nitrogen & 0.06 & 0.29 & 1.70 \\
\hline Kjeldahl nitrogen & 1.89 & 2.40 & 0.77 \\
\hline Nitrate nitrogen & 2.21 & 1.36 & 0.02 \\
\hline Nitrite nitrogen & 0.02 & 0.04 & 2.49 \\
\hline Total nitrogen & 4.15 & 3.80 & 0.06 \\
\hline Phosphate phosphorus $(\mathrm{V})$ & 0.06 & 0.08 & 0.14 \\
\hline Total phosphorus & 0.16 & 0.20 & \\
\hline
\end{tabular}

Table 4. River Liwiec basin waters ranked based on multidimensional comparative analysis

\begin{tabular}{|l|c|c|}
\hline \multicolumn{1}{|c|}{ Measurement point } & Value of synthetic variable & Rank \\
\hline Kostrzyń-Proszew & 10.90 & 2 \\
\hline Kostrzyń-Łączka & 9.92 & 2 \\
\hline Liwiec-Kamieńczyk & 9.67 & 4 \\
\hline Liwiec-Krześlin & 8.48 & 5 \\
\hline Liwiec-Borzychy & 8.41 & 6 \\
\hline Liwiec-Wólka Proszewska & 6.54 & 7 \\
\hline Muchawka Żytnia & 6.09 & 8 \\
\hline Muchawka-Rakowiec & 2.69 & \\
\hline
\end{tabular}

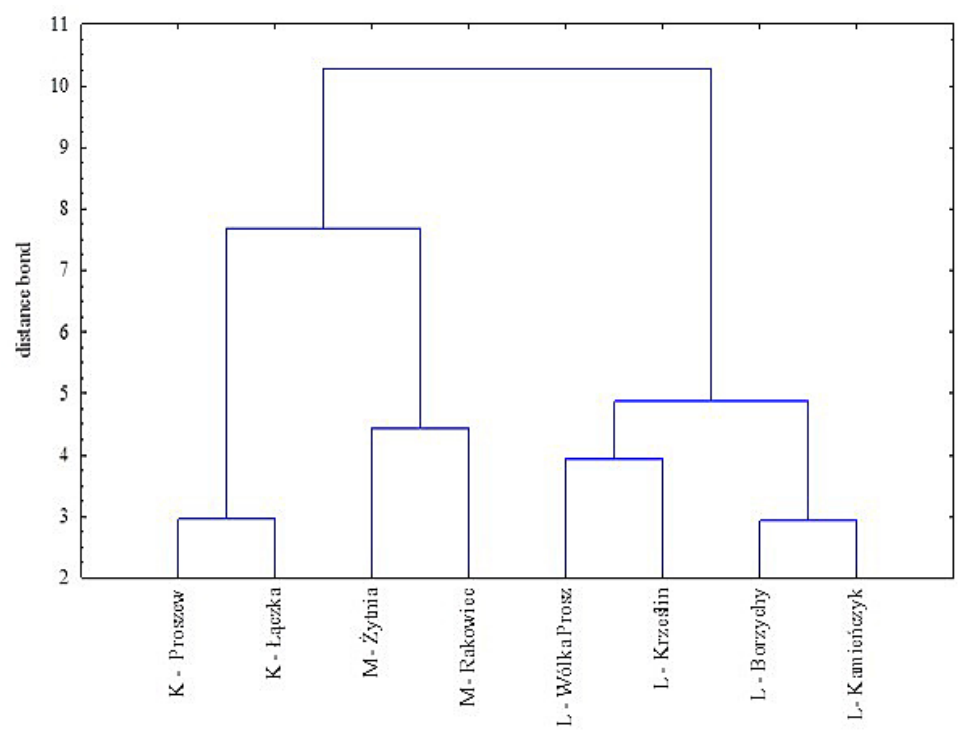

Fig. 3. Dendrogram of the division of the River Liwiec basin

3. On the basis of the cluster analysis, the measurement points in the River Liwiec were divided into 3 groups basin which had different physio-chemical parameters. The first cluster included four measurement points: LiwiecKamieńczyk, Liwiec Wólka Proszewska, Liwiec Borzychy and Liwiec Krześlin. The second cluster consisted of the Muchawka Żytnia 
and Muchawka Rakowiec tributaries, while the third one was made up of Kostrzyń Proszew and Kostrzyń Łączka

4. The waters of the measurement points forming group 1 had the highest mean values of most physio-chemical parameters. The waters in group 3 (tributary of the River Kostrzyń) had the lowest values of almost all the parameters excluding the dissolved oxygen content, ammonium and nitrite nitrogen contents, and phosphate phosphorus content.

5 . The values of the synthetic variable indicate that the water at the measurement point Kostrzyń Proszew and Kostrzyń Łączka was of the best quality, as it had the lowest values of dissolved substances. The worst parameters were found for the waters of the MuchawkaŻytnia and Muchawka-Rakowiec rivers, as they had the highest amounts of e.g.: organic carbon, phosphorus and all the nitrogen forms.

\section{REFERENCES}

1. Akin B.S., Atici T., Katircioglu H. Keskin F., 2011. Investigation of water quality on Gökçekaya dam lake using multivariate statistical analysis, in Eskişehir. Environmental Earth Sciences, 63(6), 1251-1261.

2. Bogdał A., Kowalik T., Kanownik W., Ostrowski K., Wiśnios M., 2012. Ocena stanu fizykochemicznego wód opadowych i odpływających ze zlewni potoku Wolninka. Gaz, Woda i Technika Sanitarna, 8, 362-365.

3. Bogdał A., Ostrowski K., 2007. Wpływ rolniczego użytkowania zlewni podgórskiej i opadów atmosferycznych na jakość wód odpływających z jej obszaru. Woda-Środowisko-Obszary Wiejskie, 7(20), 59-69.

4. Boyacioglu H., Boyacioglu H., 2010. Detection of seasonal variations in surface water quality using discriminant analysis. Environmental monitoring and assessment, 162(1-4), 15-20.

5. Brahman, K. D., Kazi, T. G., Afridi, H. I., Naseem, S., Arain, S. S., Wadhwa, S. K., Shah, F., 2013. Simultaneously evaluate the toxic levels of fluoride and arsenic species in underground water of Tharparkar and possible contaminant sources. A multivariate study. Ecotoxicology and Environmental Safety, 89, 95-107.

6. Górecki K., Olejnik M., 2005. Changes in levels of nitrogen compounds in water of Warta river on Oborniki-Skwierzyna stretch. Acta Sci. Pol., Form. Circ. 4(2), 21-30.
7. Grabińska B. 2011. Changes in the quality of the river water on the background of the diversity of natural conditions and usage basin. The resources conservation and water quality in rural landscape. Współczesne Problemy Kształtowania i Ochrony Środowiska. Olsztyn. UWM, 223-253.

8. Jaskuła J., Sojka M., Wicher-Dysarz, J., 2015. Analiza tendencji zmian stanu fizykochemicznego wód rzeki głównej. Inżynieria Ekologiczna, 44, 154-161.

9. Kanownik W., Kowalik T., Bogdał A., Ostrowski K., 2013. Quality categories of stream water included in a Small Retention Program. Pol. J. Environ. Stud., 22(1), 159-165.

10. Kiryluk A., Rauba M. 2011. Impact of agriculture on the concentration of total phosphorus in the surface water catchment area Ślina. Inżynieria Ekologiczna, 26, 122-132.

11. Kornaś M., Grześkowiak A., 2011. Wpływ użytkowania zlewni na kształtowanie jakości wody w zbiornikach wodnych zlewni rzeki Drawa [The impact of land use on water quality in waterreservoirs of the Drawa River catchment]. WodaŚrodowisko-Obszary Wiejskie, 11, 1(33), 125-137.

12. Kot H. (red.), 1995. Przyroda województwa siedleckiego, Zakład Badań Ekologicznych ,Ekos', Siedlce, 141-155.

13. Kukuła K., 2000. Metoda unitaryzacji zerowanej, PWN Warszawa.

14. Lampart-Kałużniacka M., Wojcieszonek A., Pikuła K., 2012. Ocena stanu ekologicznego wód rzeki Regi na odcinku w obszarze miasta Gryfice. Annual Set The Environment Protection, 14, 437-446.

15. Ławniczak A. E., Zbierska J., Kupiec J., 2008. Changes of nutrient concentrations in water sensitive to nitrate pollution from agricultural sources in the Samica Stęszewska river catchment. Annals of Warsaw University of Life Sciences Land Reclamation, 40, 15-25.

16. Mecler B., Olejnik M., 2006. Wpływ wybranych czynników na zanieczyszczenie związkami biogennymi powierzchniowych wód płynąch w zlewni Baryczy. Acta Sci. Pol., Form. Circum., 5(2), 59-71.

17. Mojena, R., 1977. Hierarchical grouping methods and stopping rule: an evaluation. The Computer Journal., 20, 359-363.

18. Mosiej J., Komorowski H., Karczmarczyk A., Suska A., 2007. Wpływ zanieczyszczeń odprowadzanych z aglomeracji łódzkiej na jakość wody w rzekach Ner i Warta. Acta Sci. Pol., Formatio Circumiectus, 6(2), 19-30.

19. Nachlik E., 2004. Identyfikacja i ocena antropogenicznych oddziaływań na wody i ich skutków wraz ze wskazaniem części wód zagrożonych nieosiągnięciem celów środowiskowych określonych prawem. Metodyka realizacji. PK, Kraków. 
20. Policht-Latawiec A., Kanownik W., Łukasik D., 2013. Wpływ zanieczyszczeń punktowych na jakość wody rzeki San. Infrastruktura i Ekologia Terenów Wiejskich, 4 (1), 253-269.

21. Policht-Latawiec, A., Żarnowiec W., Majewska M., 2015. Analiza zmienności parametrów jakościowych wody w rzece Biała Tarnowska. Inżynieria Ekologiczna, 44, 217-246.

22. Pytka, A., Jóźwiakowsk, K., Marzec, M., Gizińska, M., Sosnowska, B., 2013. Ocena wpływu zanieczyszczeń antropogenicznych na jakość wód rzeki Bochotniczanki. Infrastruktura i Ekologia Terenów Wiejskich, 3, 15-29.
23. Starczewski K., Rymuza K., Affek-Starczewska A., Pawlonka Z., Bombik A., 2014. Konkurencyjność i atrakcyjność turystyczna gmin województwa mazowieckiego położonych nad rzeką Liwiec. Acta Universitatis Lodzensis Folia Oeconomica, 6(308) 55-77.

24. Szymczyk S., Rafałowska M., 2011. The influence of the intensity of the agricultural production and the land reclamation drainage on the quality of the surface water and groundwater. In: The resources conservation and water quality in the rural landscape. Współczesne Problemy Kształtowania i Ochrony Środowiska. Olsztyn. UWM, 121-137. 